\title{
Article 39 of the Ethiopian Constitution On Secession and Self-determination: A Panacea to the Nationality Question in Africa?
}

\author{
By Ahmednasir M. Abdullahi
}

\section{Introduction}

Ethiopia's historic resistance to any form of European colonialism when the rest of Africa apart from Liberia was subjugated by European colonial powers, stands out as a glorious chapter in Africa's resistance and response to European colonialism. ${ }^{1}$ Apart from a brief period of Italian occupation, Ethiopia as a state inflicted on European colonialism one of its telling defeats in their colonization enterprise in Africa. This response optimized the aspiration of an African state which had the will and the means to counter foreign aggression and occupation. Ethiopia as a state has a long history and together with Liberia, provide an example of not only a tale of historic African tenacity and political survivability in invidious milieu but also exemplified the existence of organized societies with stable governments. It has an enduring long history of statehood with the accompanying international personality. ${ }^{2}$

Whereas Ethiopia as a state endured and triumphantly resisted "outside" aggression and occupation the same cannot be said of "internal" challenges it faced from the various ethnic nationalities that collectively form the Ethiopian state. The very sovereignty and unitary nature of the Ethiopian state has countenanced challenges from internal forces since the beginning of the twentieth century. ${ }^{3}$ Almost all the major ethnic nationalities in Ethiopia have challenged the central government at one point in time. The Somalis ${ }^{4}$, Eritreans, Oromo ${ }^{5}$ and Tigreans have singly and collectively fought the central government which

See generally Ali A. Mazrui, The Bondage of Boundaries: Why Africa's maps will be redrawn, Economist, at 32-6, September 11-7, 1993. See also Robert W. July, A history of the African People (4th ed., 1992), in which the author traces Ethiopia's existence as a state back to the 10th century and beyond.

See generally Richard Green field, Ethiopia: A new political history (1965); Margery Perham, The Government of Ethiopia (1969).

3 See generally Getachew Haile, The unity and territorial integrity of Ethiopia, 24 no. 3, Journal of Modern African Studies (1986).

4

For the Somali challenge see generally Louis Fitzgibbon, The evaded duty (1985)-

5 See generally Stephen Morrison, Ethiopia charts a new course, Joumal of Democracy, Vol. 3, no. 3, July 1992, 125-137. 
was for the whole of the twentieth century dominated by the Amhara ethnic nationality. ${ }^{6}$ Ethiopia has faced these internal challenges for it is a "nationality mosaic" with the major groups all having a historic aspiration to statehood. ${ }^{7}$ The creation of the State of Eritrea in 1994 was the final fruition of Eritrea's struggle for statehood "delivering to Africa the first country born through secession since decolonization". ${ }^{8}$

So, whereas Ethiopia has successfully resisted foreign aggression, demonstrated a pugnacious will, and has thus maintained its independence externally it had not been as successful internally. The history of Ethiopia provides a historic incongruity and contradiction of an established and well recognized external sovereignty and a lack of and/or shrinkage of internal sovereignty exhibiting the classical paradigms of defacto and de jure manifestation of these two forms of sovereignty. ${ }^{9}$ Ethiopians of all ethnic nationality have interminably shown their aversion to the central government and their yearning for selfdetermination and secession has a long enduring chronicle.

This historic paradox was finally resolved by the new regime of Prime Minister Meles Zanawi that deposed the former government of Mengistu Haile Maraim. After assuming power, the new regime took a fundamental decision that transformed the power politics and even the very structure of the Ethiopian state. Taking a realistic approach of the political variables of the country, their experience and the global trend, the new regime undertook a restructuring program that has a constitutional engineering core as its foundation in order to remold and recast the institution of state in Ethiopia. ${ }^{10}$ They made the various ethnic nationalities the center of statal gravity. The Ethiopian government during a transition period adopted an interim constitution that was an innovative piece of constitutional document in Africa. It allowed ethnic nationalities the right to secessionist self-determination. It

For the view that Ethiopia is better off as unitary state and further that self-determination based on ethnic self-determination should not be implemented in Ethiopia as it is counter-productive, see Hizkias Assefa, Crucible of civilization and conflicts: Ethiopia, in: P. Anyang' Nyong'o (ed.), Arms and daggers in the heart of Africa: Studies on internal conflicts (1993), pp. 15-32.

Asmelash Beyene, The nationality question, secession and constitutionalism: The case of Ethiopia, in Issa G. Shivji (ed.), State and Constitutionalism: An African debate on democracy (1991), p. 129, at p. 130.

Another Country, Economist, April 24th, 1994, at p. 20.

The authority and intermal sovereignty of most African States has been constantly eroded by the pressure exerted by ethnic communities who are at the periphery of the state and exert a prodemocracy pressure on the state, see David Held, Democracy, the Nation-State and the Global System, in: David Held (ed.), Political Theory Today, (1991), pp. 197-235 (explaining how the nation-state is facing democratization forces globally and has to change with the realities of the day).

10 For their vision and attempt to restructure the system of the country, see Human Rights Watch Africa, Ethiopia: Reckoning under the law (1994). 
also allowed internal self-determination within a federal system of government creating various regional governments that are ethnically based. ${ }^{11}$

This paper analyzes the constitutional right of peoples to secessionist self-determination in both the interim constitution and the current constitution of Ethiopia. In this respect we decipher into the constitutional implications of such inclusion and attempt to see whether this inclusion is a precursor of a new chapter in modern governance in the African state or a passing fade for pro hac vice of the current regime. We also analyze the frontiers of Article 39 of the Ethiopian constitution, that is its expanse and delimitations and see in the final analysis whether it adds to or subtracts from the position of general international law on secession and self-determination. Is article 39 the answer to the national question that has bedeviled the African state for the last thirty years? ${ }^{12}$ Does it democratize the state in Africa? Is this a new political philosophy as to how the state ought to be governed by directly empowering the various ethnic nationalities? Is Ethiopia leading the way, and should the rest of Africa follow, or is Ethiopia opening a pandora box? Finally does the incorporation of ethnic secessionist self-determination heralds the realization of the importance and an acceptance of ethnicity as a value system in Africa's political setup?

\section{Secessionist self-determination and the Ethiopian constitutions, 1991-94}

Ethiopia's constitutional structure has gone full circle. The format of the Ethiopian state has been through all known models of governance, from absolute monarchy with a feudal tinge during the Haile Selaise's regime and the predecessors kings of Ethiopia, military dictatorship with marxist garb during the rein of Mengistu Haile Mariam and lastly the current Ethnic remolding of the state under Meles Zenawi. The radical adoption and the transformation of the state making ethnic nationalities the center of state organization perhaps evince the bankruptcy of the preceding modes and structures of the Ethiopian state and is

Article 2 of the Interim Charter stated: "The right of nations, nationalities and peoples to selfdetermination is affirmed. To this end, each nation, nationality and people is guaranteed the right to:

a) Preserve its identity and have it respected, promote its culture and history and use and develop its language;

b) Administer its own affairs within its own defined territory and effectively participate in the central govermment on the basis of freedom, and fair and proper representation;

c) Exercise its right to self-determination of independence, when the concerned, nation / nationality and people is convinced that the above rights are denied, abridged or abrogated.

Transitional Period Charter of Ethiopia, no. 1, Negarit Gazeta, Addis Ababa, 22nd July 1991.

Many African countries face the threat posed by the conflict between the various ethnic groups in the state and as to how ethnic rivalries contribute to such a conflict in Uganda, see Yoramu Barongo, Ethnic pluralism and political centralization: the basis of political conflict, in: Kumar Rupensinghe (ed.), Conflict Resolution in Uganda (1989), pp. 65-90. 
precursor to new but desperate attempt to make the state relevant in Africa's political scene. Apart from being a bold experimentation, the inclusion of ethnic self-determination that allows dissatisfied ethnic nationalities the right to secede could be a realization that ethnicity instead of being dismissed or wished away should be incorporated constitutionally and the institution of the state should reflect the ethnic composition of the state accordingly. ${ }^{13}$

The right of peoples to secessionist self-determination is by its very nature a radical right. Even more radical is the inclusion of such a right into the constitution of an African state. Ethiopia has definitely brought a new novelty to the constitutional foundation of the state in Africa. For in an express provision it provides for the "winding up" of the Ethiopian state by the various ethnic nationalities that collectively form the state if any of them is dissatisfied with the unitary policies of the state towards their people, nations or nationality.

\section{a) Article 39 of the Ethiopian Constitution: the extent of its frontiers}

Article 39 provides:

"(1) Every nation, nationality and people has an unconditional right to self-determination including the right to secession.

(2) Every nation, nationality and people in Ethiopia has the right to speak, to write and to develop its own language; to express and to promote its culture; and to preserve its history.

(3) Every nation, nationality and people in Ethiopia has the right to a full measure of self-government which includes the right to establish institutions of government in the territory that it inhabits and to equitable representation in regional and national governments.

(4) The exercise of self-determination, include secession of every nation, nationality and people in Ethiopia is governed by the following procedures:

(a) when a demand for secession has been approved by a two-third majority of the members of legislative council of any nation, nationality or people;

(b) when the Federal Government has organized a referendum which must take place within three years from the time it received the concerned Council's decision to secession;

See generally Ahmednasir M. Abdullahi, Winding up the State: Why African States should legislate secession as a constitutional right for ethnic nationalities, in: Joseph Olakaonyango et al. (eds.), Law and the struggle for democracy in East Africa (1996), pp. 372-390 (arguing that the various wars of secession in the African continent are usually a last desperate attempt by an oppressed ethnic nationality and are rarely jingoistic or nationalistic adventures on the part of an ethnic group). 
(c) when the demand for secession is supported by a majority vote in the referendum;

(d) when the Federal Government will have transferred to the people or their council its powers; and

(e) when the division of assets is effected on the basis of law enacted for that purpose.

(5) A nation, nationality or people for the purpose of this constitution is a group of people who have or share a large measure of a common culture, or similar customs, mutual intelligibility of language, belief in a common or related identities, and who predominantly inhabit an identifiable, contiguous territory."

Article 39 of the Ethiopian constitution is a unique provision in two ways. Constitutionally, it inaugurates the right of communities or group rights within the context of the African state and transplants the same into a substantive constitutional provision. ${ }^{14}$ Second, from an international law perspective it incorporates a fundamental but radical norm of international law into the municipal legal regime of an African state, a remarkable act in the African continent. ${ }^{15}$ The Ethiopian constitution under article 1 establishes constitutionally the sovereign state of Ethiopia as a juridic entity and through article 39 provides the precise antipode of the existence of the state it so create. In thus establishes a constitutional provision for the folding up of the state. In other words, the constitution that forms the juridic basis of the state in the same breath provides for its demise, peacefully and constitutionally.

Article 39 (1) is a restatement of international law's position on the right of nations, nationalities and people to secession and self-determination. It addresses the two levels of selfdetermination, internally within the state and externally from the state through secession. The later leading to the creation of a new state through secessionist self-determination. ${ }^{16}$

Communal or group rights are not a common constitutional right in the constitutions of African states. Instead most African constitutions are based on the liberal notions of the state and the rights addressed therein are individual rights. This is a result of the colonial legacy in the continent. For this historical legacy see J.B. Ojwang, Liberal values in African constitutional development: some reflections, African Society of International and Comparative Law, Proceedings of the Third Annual Conference (1991), pp. 19-31.

For the attitude of African states to the concept of self-determination see generally Nana K.A. Busia $J R$, The right to self-determination, the state and the quest for democracy in Africa: an exploratory analysis, African Society of International and Comparative Law, Proceedings of the Fourth Annual Conference (1992), pp. 29-48.

See generally Antonio Cassese, The Helsinki Declaration and self-determination, in: T. Buergenthal / J. Hall (eds.), Human rights, intemational law and the Helsinki Accord (1977); Antonio Cassese, The self-determination of peoples, in: L. Henkin, The Intemational Bill of Rights: The Covenant of Civil and Political Rights (1981). See also Jean Salmon, Internal aspects of the right to self-determination: Towards a democratic legitimacy principle?, in: Christian Tomuschat (ed.), Modem law of self-determination (1993), pp. 253-282. 
The gist of the article reveals and underlines the two traditional facets of the rights. Whereas the right of peoples to self-determination is expressly and affirmatively stated, the inclusion of secession as a distinct form of self-determination clearly raises two issues. First, nations, nationalities and peoples within the Ethiopian state are given the right to internal self-determination within a federal structure. In this regard the constitution mandates the creation of 15 regions that forms the federal states and the same are exclusively created on ethnic basis. ${ }^{17}$ Second, these groups are further given the right to secede if they so wish and form their own new states under article 39. The ultimate and exclusive right to trigger secession is thus placed in the hands of these ethnically based states. Secession is explicitly and quite deliberately established as discrete form of self-determination which according to the provision should lead to the creation of a new state. It therefore illuminates the clear definitive contours of the right to secede and further emphasis the establishment of the right affirmatively and unequivocally.

Two sub-sections of article 39 are also important. 39 (4) is indeed crucial. It establishes an elaborate mechanism to be followed when the holder of the right to secede tries to exercise it. In this regard, the procedure is elaborate and it further provides for the facilitating role to be played by the Ethiopian State in the process. Under 39 (4) (a) a demand for secession has to be approved by two third majority of the members of the Legislative Council of any nation, nationality or people. This provides an important check against any thoughtless or purely jingoistic agitation for secession. It pegs the right to secession on the majority of the parliamentarians in the concerned State Assembly as representatives of the people who want to secede. As a starting point, the right to secede can only be constitutionally triggered by the Legislative Assembly of the seceding state. This is a judicious and democratic way of ascertaining that the will of the people through their democratically elected leaders should be the custodians of the right.

After the concerned legislature passes a resolution to secede, the Federal Government under article 39 (4) (b) has to organize a referendum within the seceding state in order to double check as to whether or not the resolution of the Legislative Assembly is a true reflection of the will of the majority of the people, nation or nationality within the concerned state. This must take place within three years after receiving the vote of the Legislative Council. This . provision makes sure that the majority of the people within the region are in support of secession. It provides a two tier mechanism which in concurrence have to lead to the only conclusion, that the majority of the people within that state are for secession. This is further

Article 47 of the constitution, which establishes the right of intermal self-determination, states:

"(1) Member states of the Federal Democratic Republic of Ethiopia are the following: 1. Tigrai, 2. Afar, 3. Amara,, 4. Oromia, 5. Somali, 6. Benshangul / Gumaz, 7. Southem Nations, Nationalities and Peoples, 8. Gambela Peoples, 9. Harari People.

(2) Nations, nationalities and peoples within the states enumerated in sub-article (1) of this article have the right to establish, at any time, their own states." 
buttressed by article 39 (4) (c) which mandates that for secession to be allowed the majority of the participants in the referendum to be subsequently organized must be in support of secession. It establishes a simple majority and not an absolute one. Once the above three events occur in methodological sequence, then under 39 (4) (d) the Federal Government transfers "to the people or to their councils its powers". This is a very important section that underlines yet again the "good faith" role of the Federal Government of Ethiopia and the organized manner of implementing the right to secession. Once a majority of the people vote for secession in the referendum, the Federal Government divests itself of all its sovereign powers and transfers the same to the new state so created and ceases to exist as the sovereign vis-à-vis the new state. Under subsection (e) assets have to be divided between the new state and the Federal Government of Ethiopia.

Article 39 (5) adds a further clarity to the breadth and width of who is entitled to secede under the constitution. It elucidates a pertinent question of international law, in that it answers the question who is the "self" that has the right to determine its destiny? It defines who is the nation, nationality and peoples who for the purposes of the constitution can secede or exercise the right to secession. It formulates a working definition of who is entitled to the right. This provision not only delimits the frontiers of who the self is but it also identifies the possessors who can exercise the right of peoples to secessionist selfdetermination. The controlling criterion are thus, a common culture, same language, identity or common heritage and inhabiting a particular territory. It is significant that religion is not explicitly mentioned, the probable reason being that various ethnic groups in Ethiopia have substantial number of their people professing either Islam or Christianity. Article 39 is comprehensive postulation of all the issues that normally concern the right to secede and self-determination. One, it firstly establishes the constitutional right of ethnic nationalities to secede from the state of Ethiopia. After that it lays an elaborate and effective procedure to be followed on the road to secession. Lastly, it quite importantly defines who the right holders are, that is it defines the nation, nationality and peoples who are entitled to exercise the right to secessionist self-determination.

\section{b) Article 39 and secession under international law: how revolutionary is Article 39?}

Inasmuch as Article 39 establishes a very radical constitutional provision, the same in reality may be restatement of the international law position on the subject. One could however notice some obvious but deliberate omission. Secession due to its radical content and drastic consequences has historically been treated with some superficiality and subjected to statal suspicion both as an issue of political philosophy and as a concept of 
international law. ${ }^{18}$ The historic mistreatment meted out to the right of peoples to secession and self-determination was mainly due to the fact that these species of rights can only be exercised by peoples against their states. States being the main players on the international plane, a plane where much of international is legislated are naturally hostile to any right exercisable against them especially when the same impinges on their sovereignty and territorial integrity. States have in this regard exercised all blockages against the right to secede, after all they have skeletons in their closets to hide. ${ }^{19}$

Notwithstanding state hostility and traditional limitations on these rights, secession and self-determination have over the years bloomed to full legal rights and under certain circumstances may have attained a jus cogens status under international law. ${ }^{20}$ During its formative stages of development all kinds of limitations were thrown on its path and unrealistic contours drawn around it. Attempts were made to restrict the scope of the principle on such tests as "salt water" and "pigmentation" or color. ${ }^{21}$ The former required some oceanic separation between the seceding state and the parent state from which it secedes from, while the later required the two parties to be of different color. ${ }^{22}$ Despite this dilatory attempts secession and self-determination are now accepted as legal rights belonging to nations, nationalities and peoples. ${ }^{23}$ That these rights are accepted legal rights has been fortified by the events following the end of the cold war and demise of the Eastern block countries. Through these historic events "one can detect a weakening in the existing taboo against secession, indeed the signs of an emerging paradigm shift whereby secession will no longer be treated as unthinkable in the international system" ${ }^{24}$.

The argument for and against secession is usually presented as a clash between the right of the parent state to territorial integrity and sovereignty on one hand, and the human rights of particular peoples within that country to determine their political destiny. Whereas international law affirms the right of the state to territorial integrity as against other states, the

See generally Albert Taylor Bledsoe, Is Davis a traitor or was secession a constitutional right prior to the war of 1861 (1866). See also Dietrich Murswiek, The issue of a right to secession - reconsidered, in: Christian Tomuschat, supra note 16, pp. 21-39.

Falk Richard, The Right of Peoples (in particular indigenous peoples), in: Crawford Richard, The Right of Peoples (19929; p. 17.

See U.O. Umozurike, Self-determination in intermational law (1972).

Allen Buchanan, Self-determination and the right to secede, Joumal of International Affairs, 45 (1992), p. 349. Id.

See generally Francesco Capotorti, Study on the Rights of Persons belonging to ethnic, religious and linguistic minorities, UN Doc. E/Cn.4/Sub. 2/384/Rev. 1 (1979).

Alexis Heraclides, Secession, Self-determination and Non-intervention: In quest of a normative symbiosis, Joumal of Intermational Affairs, 45 (1992), p. 399. 
state has no such right against its own nationals under international law. No known norm of international law exists that inhibits citizens of a country to secede from the parent state. The right to secede however is not an absolute right that can be exercised by every one under some self-serving circumstances. It is now well established that some universally accepted conducive factors for secession must exist for the right holder to exercise it. In expounding juridically, the right to secede, scholars are of the opinion that there must be justifiable reasons to do so. It is a right that is triggered by some misfortune or abuses against the right holder that are attributable in whole to the parent state's policy towards a particular people.

Various justifications have been propounded by scholars as to when the right to secede can be exercised. According to Allen Buchanan, "the most obviously compelling justification for secession may be called the argument for rectifictory justice" ${ }^{25}$. This argument is premised on the theory that the people who are exercising the right to secede are just recalling or retaking what was legitimately theirs. He makes the common law analogy of the recovery by the legitimate owner of goods stolen from him by a thief. ${ }^{26}$ This according Lea Brilmayer is "historical grievance version of the territoriality thesis" ${ }^{27}$ Her argument goes that any claim by community to secede must be based on a historic claim to a territory. The land they inhabit provides a historic symbol of both their uniqueness and their potential for statehood.

Discrimination against a nation, nationality or people also provides a legal justification to secede. The victims of discrimination have to demonstrate that they are victims of discriminatory redistribution at the hands of the state. ${ }^{28}$ This mode of human right abuses against the right holder is considered a serious violation of human rights that can trigger the exercise of the right to secede as an ultimate redress of their human rights violation. ${ }^{29}$ The

25

26

27

28

29

Alexis Heraclides, supra note 24 at p. 411 , suggests four core qualifications or factors to be considered under which the right to secession can be exercised:

1. systematic discrimination against minority group;

2. the existence of a distinct group, nation, nationality or people with a state which overwhelmingly support secession;

3. the possibility of peace between the two states and a good chance of co-existence;

4. the rejection of comprise solution or concession by the central government.

Abdullahi An-na'im suggests a similar criterion to be followed in assessing the right of selfdetermination:

1. the degree of internal cohesion and unity within the group;

2. the quantum of their claim; 
right to secession is also exercisable when the people who are agitating to secede from the rest of the state "can not longer live in peace and security or fulfil their legitimate individual aspirations within the larger political community" ${ }^{30}$ On top of these factors a legitimate claim for secession must demonstrate that the claimant is in fact of such composition that it is capable for existing as a viable political entity. It must be able to establish and sustain an international personality on its own or in union with another entity. ${ }^{31}$ This viability of the entity as an international personality raises two issues, first, the new state must be capable of independent political existence as a state and second, it must be viable politically with the distinct chance of survivability in future. ${ }^{32}$

Africa's riposte adducible both from the practice of states and even the theorizing by most African scholars points to a total rejection of secessionist self-determination in postcolonial Africa. ${ }^{33}$ This unenlightened position is a product of Africa's past history of dictatorship and human rights abuses in an era characterized by the absolutism of state power and gross abuse of human rights against the people. It was too much to expect of these African states to allow the right of peoples to self-determination and secession when most of them failed not only to observe the basic human rights of their citizens but to certain extent implemented policies that were gross violations of human rights as state policies. Because any form of self-determination has sometimes been referred to as the right

3. the rationale or reasons that underline their agitation;

4. the level of human rights abuse against the group.

Abdullahi An-na'im, The national question, secession and constitutionalism: The mediation of competing claims to self-determination, in: Shivji, supra note 7, at p. 101, 110.

This same points are stated by Ved P. Nanda, Self-determination under international law: validity of claims to secede, 13 case Westem Reserve Journal of International Law (1981), at p. 275.

O. Kamanu, Secession and the right of self-determination: an OAU dilemma, Joumal of Modem African Studies, 12 (1974), at p. 361.

31

Lee C. Buchheit, Secession: the legitimacy of self-determination (1978), pp. 228-230.

32

Id., at p. 230.

A prominent exception in this regard amongst scholars is Issa G. Shivji. Commenting on the fallacy that secession and self-determination has no place in post-colonial Africa he states: "Restriction of right to self-determination to colonial and colonial-like situations (South Africa) in the state practice .... and the absolutising of the principle of territorial integrity is based on two rationale. On the one hand there is the fear that the recognition of this right would lead to dismemberment of states and encouragement of secessionist movements and on the other it will provide a fertile ground to foreign powers to support such movements thereby weakening the sovereignty of the African states. ... Recognition of the right to secede does not automatically mean that every nation or people have a duty to secede; indeed, the fathers of this rights believed that the very recognition of the right to secede and democratic treatment of all nations and nationalities within a particular state lead to a situation of voluntary union of nations rather than secession. ... [T]he right belongs to an oppressed nation and if a nation is not oppressed, that is to say, it is treated democratically and accorded equality, both the reason and rationale for secession disappear." Issa G. Shivji, The concept of human rights in Africa (1989), p. 74. 
of the winner in a Darwinian conflict for survival ${ }^{34}$, African states strongly countered the notion of secession as a right applicable to any section of their subjects once independence was attained. African states have successfully used the right of sovereignty and territorial integrity and even the right to development as a shield to completely rule out the right to secession and self-determination. ${ }^{35}$ The right of peoples to secession and self-determination have suffered greatly as result of this history era of dictatorship in Africa. ${ }^{36}$ They developed a reactionary stand that self-determination of any form has no relevance or life span beyond decolonization, and such right is inapplicable against a Black African state.

African states' principle objection to the exercise of this right is a derivative of a despotic order based on a physical protection of land to safeguard their territorial perimeters. Due to the ethnic composition of the state in Africa and the truancy of any cohesive factors within the state, which is further aggravated by the absence of the nation-state, African governments quite naturally developed hostility towards this group rights. ${ }^{38}$ African states because their grip or rule over their citizens was rarely democratic could not allow a section of their population to secede for fears of a perceived domino effect throughout the continent. ${ }^{39}$ The contention of the African states has little if any legal pertinence in so far the true juridic nature of the right to secede is concerned. ${ }^{40}$ The basic underlying factors that allow the right of peoples to secession or self-determination usually emanates from the inauspicious conditions of the peoples within the state. Issues of human rights abuses, discrimination and underdevelopment are the controlling factors and the true legal issues to be considered and not the political spurning of the state. The right to secede has as much relevance and applicability in post-colonial Africa as it did during the colonial days. It is applicable once

The views of Emperor Haile Selassie on the Biafra case gives an appropriate and representative view of the African leaders. He said: "The Organization of African Unity is both in words and deed committed to the principle of unity and territorial integrity of its member states... The national unity and territorial integrity of member states is not negotiable. It must be fully respected and preserved", quoted in D.A. Ijalaye, Was Biafra at any time a state in international law?, American Journal of International Law, 65 (1971), p. 556.

See generally Addo, Political self-determination within the context of the African Charter on Human and Peoples' Rights, Journal of African Law, 32 (1988).

S. Kwaw Nyameke Blay, Changing African perspectives on the right of self-determination in the wake of Banjul Charter on Human and Peoples Rights, Journal of African Law, 29 (1985), p. 147.

For the diversity of the ethnic base of the states in Africa and the absence of the nation-state see generally Basil Davidson, The black man's burden: Af rica and the curse of the nation-state (1992).

39 This has been shown by the Eritrean experience to be inapplicable and the argument by the states in Africa that self-determination in one country will lead to the break-up of other is clearly baseless, see Shiv ji, supra note 33.

40

For the traditional arguments advanced by African states accepted and developed through the Organization of African Unity (OAU) see generally Ian Goddard, The national question in independent Africa, Hom of Africa, Vol. 1, no.. 3 (1978), pp. 51-58. 
the controlling indicia for the exercise of the right like, subjugation, domination and exploitation of right holders exist with a certain geographical area. ${ }^{41}$

The Ethiopian constitution through article 39 in addition to being a restatement of the international law's position on secession and self-determination, nevertheless goes further. In remarkable departure, it also departs from the position of the interim constitution which gave the reason or factors that can trigger the exercise by an ethnic community or people to agitate or implement their constitutional right to secede. Like international law the interim constitution set out persuasive reasons that could compel the people or nationality to exercise the right to secede. ${ }^{42}$ The exclusion of the factors to be considered in the exercise of the right to secession and self-determination in the current constitution makes the exercise of the right much easier and practical, but it could have a dangerous consequence in that it freely avails such a drastic right to all nations, nationalities and people. But the danger of reckless use of the right seem farfetched in that the philosophy that underlines the constitution and even the state of Ethiopia is a voluntary union of tribes, nationalities and people. Article 39 allows the same free union to be dissolved or at least altered by any member who is no longer satisfied with the status quo in Ethiopia as a state.

\section{The ethnic factor in the African state: Is Ethiopia showing the right way?}

The nationality problem in Africa has a long history of creating conflict and instability within the states in Africa. Ethnic tension and antagonism is the whole mark of many states in Africa and so far is the single most important fact leading to the disintegration of states. The tribe is still the most vital player in the political scene of the state in Africa. Many states who ignored the same did so at their peril, and quite a number have disintegrated as a result. ${ }^{43}$ The very composition of the African state has historically created tensions within the state. Struggles triggered by nationality aspiration for statehood, autonomy or a general tribal dissatisfaction with the state has plagued most of the African states. ${ }^{44}$ Underlying these struggles is inequality between the various ethnic nationalities, discrimination and

Robert McCorquodale, Self-determination beyond the colonial context and its potential impact on Africa, African Journal of International Law (1992), p. 608.

See the interim Transitional Charter, supra note 11.

For the new phenomenon of state disintegration and the problems created as result see Ruth E. Gordon, Some legal problems with trusteeship, Comell. Intemational Law Joumal, 20 (1995), pp. 301-347; Jon H. Sylvester, Sub-saharan Africa: economic stagnation, political disintegration and the specter of recolonization, Loy. L.A. L. Rev., 27 (1994), p. 1299

For the tribal imbalances in most African states and how the same leads to intra-state conflict, breakdown of the institution of the state and ultimately leads to loss of life and refugee crisis, see Ahmednasir M. Abdullahi, The refugee crisis in Africa as a crisis of the institution of the state, IJRL, 6 (1994), pp. 562-580. 
abuse of human rights. ${ }^{45}$ This is as result of lack of any state enactment or constitutional provision that mediate between the various ethnic groups. Because no state has developed a legal or constitutional way of addressing the most fundamental question facing the state in Africa none has really overcome the pestilence of ethnic tension. The killer disease of the state in Africa has been the inability of the state to give a legal address or dimension to ethnicity or the national question within its constitutional structures. Not one country in Africa has attempted to address the consequences or multi-ethnic dimension of the state, juridically. None has implemented a policy of constitutional equality amongst the various ethnic nationalities in the country. Yet, in Africa, ethnic rivalry between the communities has always lead to serious consequences and even the disintegration of the state as in Somalia, Rwanda, Burundi, Liberia and many others.

Despite the existence of such a national question as to how to address the ethnic factor few African states have given this question a serious thought. ${ }^{46}$ The breakdown and instance of disappearances of some countries in the African continent is as result of inability to formulate a statal policy that is responsive to and is a reflection of the true factual tribal scenario in the typical African state. Most of the hostilities in Africa that bets on ethnic nationality against another leading to breakdown of the state is as result of a conflict "where two or more ethnic groups constituting a territorial sovereign state live in mutual suspicion or distrust a rising from a perceived or actual monopoly of political power by one or more such groups and exclusion of others from such power" ${ }^{47}$. The African states due the nature of its ethnic composition has to establish a realistic workable multi-ethnic modus vivendi in order to survive as viable political entity. ${ }^{48}$

Issa G. Shivji, State and constitutionalism: a new democratic perspective, in: Shivji (ed.), supra note 7, at p. 33.

46 "African political leaders, experiencing it as destructive to their ideals of national unity, denounce it passionately. Commentators on the left, recognizing it as a block to the growth of appropriate class awareness, inveigh against it as a case of 'false consciousness'. Apologists for South Africa apartheid, welcoming it as an ally of continued white dominance, encourage it. Development theorists, perceive it as a check to economic growth, deplore it. Journalists, judging it an adequate explanation for a myriad of otherwise puzzling events, deploy it mercilessly. Political scientists, intrigued by its continuing power, probe at it endlessly. If one disapproves of the phenomenon, 'it' is 'tribalism'; if one is less judgmental 'it', is 'ethnicity'." Leroy Vail, Introduction: Ethnicity in Southern African history 1, in: Leroy Vail (ed.), The creation of tribalism in Southern Africa (1989).

Michael S.O. Olisa, Standing on sinking sand: ECOMOC and the Liberian internal conflict, in: $P$. Any'ang' Nyong'o (ed.), supra note 6, p. 261, 269.

E.J. Hobsbawm, Nations and nationalism since 1780: program, myth, reality (2nd ed. 1992), pp. 154-155. "In post-colonial Africa, ethnicity continues to be a ma jor factor conditioning success or failure of the state", Ali A. Mazrui, The African state as a political refugee: institutional collapse and human displacement, IJRL (1995), Special Issue, pp. 21-36. 
Ethnic communities in Africa fight for the institutions and organs of the central government and see them as a valuable economic enterprise. Usually a tribe or a coalition of tribes confederate themselves in order to a have monopolistic grip on the institutions of the state. This naturally excludes other ethnic groups, and their very exclusion leaves them with no alternative but to break that monopoly, usually through the use of force which may lead to the disintegration of the state and the formation of new state. When matters came to this point the only way out is to recast the state in such manner that it addresses the problem that led to the spark and the subsequent explosion. Ethnicity and the sharing of resources must be addressed constitutionally if the state in Africa is to be reshaped as a viable political enterprise. ${ }^{49}$

The decentralization of power a long ethnic lines always leads to empowerment of ethnic nationalities. It creates power at the peripheries, weakens the central government and relocates power to communities. Apart from this the central government to an extent is weakened in that there has been a divesture or transfer of power to the federal states. A case in hand was the diffusion of power in Nigeria. Due to the constant jostling for power between the largest three ethnic nationalities, the Nigerian government after the failed secession of Biafra in 1967 broke up the three dominant ethnic groups and replaced "the tripartite division within nineteen smaller states" ${ }^{50}$. The constitutional provision in the Ethiopian constitution allowing nations, nationalities and peoples the right to secede is both revolutionary and appropriate. It firstly underlines the nature of an entity (the ethnic nationalities) that is so crucial yet so discarded by the African state. It gives ethnic groups a constitutional recognition and accepts them as the player in the power politics of the country. Because the state is amalgamation of various ethnic nationalities, the constitution not only recognizes that union but also through Article 39 empowers them to secede and wind up the state when it fails to live up to its objectives of incorporation.

African states faced with the national question have adopted either of two strategy in dealing with the same, fight the ethnic genie officially, then sideline most of the ethnic groups and practice it behind the scene, or wish it way-assume it has no relevance or existence in the country. Ethiopia seems to add a third option - recognize it, and then accommodate it constitutionally. This recognition creates equality, checks and balances and assures that unlike most of Africa, the institutions of the state is not dominated by just one tribe. Ethiopia with over 80 ethnic groups by allowing ethnic communities the right to secede undertakes "a radical experiment in democracy that could serve as a model for other

Michael Olisa commenting on a solution to the Liberian conflict states: "... [T] he reformulation of the structure and content of the Liberian state is an indispensable and urgent step in the way to 50 peaceful and lasting settlement of the Liberian conflict." Olisa, supra note 47, at p. 285.

Hobsbawm, supra not 48, at p. 154. 
tribal torn nations in Africa" ${ }^{51}$. This constitutional provision also breaths in new and fresh approach to politics in Africa, at least theoretically. Violence and civil wars are the only ways in which the case for secession and self-determination are normally addressed and settled in Africa. This constitutional provision points to a peaceful, a uniquely civilized way of solving such disputes. It also uniquely recasts the state in another perspective and empowers the people and regions. It divests power from the central government which has historically act as organ of oppression. It is an appropriate "device that will encourage cultural diversity and minimize friction among Ethiopia's tribes" 52

It is time that African states with heterogeneous communities or population follow the Ethiopian example. It does not mean that the constitutional incorporation of secession will automatically lead to dismembering of the state. Far from it, in fact it demystifies the myth that every tribe in Africa wants to create its own state through secession and self-determination. It makes the state more responsive and caring to the wishes and aspiration of all of its constituencies. Most importantly by empowering ethnic groups with such a right, it checks the excesses of the state, it also redistributes the power of the various components of the state in the African context. It could be the most powerful factor that limits the power of the African state and the biggest provision that leads to respect for human rights on a continental scale. Such a provision is also in line with global trends whereby the international community has now focused on the need for certain ethnic groups to secede and create their own states when their previous state is either no longer viable or due to abuse of their human rights, and Africa should do likewise. ${ }^{53}$ It also mitigates a historical irony that African states who attained independence through the principle of self-determination have refused to extend the same right to peoples within their territory. This political-legal paradox and hypocritical stance is the product of one man rule, lack of ideals on and continental scale a continental policy of human rights abuse. ${ }^{54}$

51 Power to the people. Ethiopia: Meles bets on radical reforms, Newsweek, July 17, 1995, at p. 19.

52 Id.

Herbst, Challenges to Africa's boundaries in the New World Order, Joumal of International Affairs, 46 (1992), p. 23.

54

Franck and Hawkins commenting on this stated: "Powerful African and Asian states, themselves only recently freed from alien rule, felt free to send military aid to other govemments dealing with disaffected minorities seeking independence. Most remarkable is the recent spectacle of India providing troops to suppress the secessionist movement in Sri Lanka mounted by the Tamils of Indian origin. There are other such paradoxes. Nigeria sought and received military assistance from its former colonial masters, the British, to extinguish the secessionist Ibo state of Biafra. Zimbabwe, having only recently gained control of the country from its white settlers vigorously used a largely white-led militia to suppress secessionism among the Ndebele tribe in the western region." Thomas M. Franck/Steven W. Hawkins, Justice in the Intemational System, Michigan Joumal of Intermational Law, 10 (1989), pp. 148-149. 
African states should jettison the romantic vision they have of the current border regime and embrace ideals that are responsive to the human rights aspiration of their citizens. For the past thirty years Africa has idolized these borders at the alter of creating human tragedy and it is time to take stock of this state obsession with the current borders regime even if the same could lead to the reorganizing and restructuring of states or even dismembering of some states.

\section{Conclusion}

Ethiopia is probably the oldest organized state on the African continent. It is one country that has experimented with many forms of governance and all political theories of the state have been tested to their very limits. It is now unveiling a new form of political governance which empowers all the people of the country through various forms of self-determination, including the right to secede. It has reinvented the state in Africa, adopts an indigenous form of governance whereby the various ethnic nationalities have an overwhelming power over the central government and gives the state in Africa for the first time an "African look". It divests power from the central government and empowers the regions which are controlled by the various ethnic groups. In this way, the central government which historically committed gross abuse of human rights against its citizen usually on ethnic grounds has its powers drastically curtailed. Only someone who has no veneration for the human rights of nations, nationalities and people will cry for the old order. 


\title{
ABSTRACTS
}

\section{Legal Uncertainty, Plurality of Legal Norms and Social 'Anomy' in Latin America}

\author{
By Peter Waldmann
}

The article's subject is the competition between formal and informal rules in Latin America. First, it shows the deficiencies of formal law in these countries. Then it develops a scheme of different forms of the relationship between formal and informal order defining them as "complementarity", "dualism" and "autonomy in the shadow of Leviathan". In extreme cases where no clear structures are visible anymore it propones to speak of "anomy". In the final section the article draws some conclusion from the heterogeneity of rules prevalent in this region.

\section{Article 39 of the Ethiopian Constitution on Secession and Self-determination:}

\section{A Panacea to the Nationality Question in Africa?}

\section{By Ahmednasir M. Abdullahi}

This paper addresses an innovative constitutional provision of the Ethiopian constitution. Ethiopia as the oldest state in Africa has gone full circle in constitutional engineering. At one time it was a feudal monarchy, replaced by marxist dictatorship, punctuated by various ethnic rebellion, culminating in the creation of Eritrea through secessionist self-determination and the constitutional incorporation of the right of secession and self-determination in the current constitution.

Considering the role of ethnicity in state (mis)management, the inability of the state in Africa to address this issue legally and violent consequences it had on the state in Africa, this article argues that the present article 39 of the constitution is an innovative provision that addresses the aspiration of ethnic groups and allows a safety valve in the winding up of the state in Africa. The article within the context of state management in Africa for the first time envisages a scenario in which the life span of the state is delimited.

Article 39 provides a civilized way of ending the state when the various ethnic component of the state in Africa fail to agree on how to live with each other. This article is worth copying. 